Conclusions:-The interest of the case lies in the following points :-

1. The development of an opacity in the posterior layers of the left cornea unattended by any inflammatory reaction.

2. The restriction of this opacity to the cornea of one eye only; whether this was due to the treatment adopted, it is not, of course, possible to say.

3 . The subsequent development of eight dioptres of hypermetropia, with an alteration of $60^{\circ}$ in the axis of the astigmatism.

\title{
B.WELCHII INFECTION OF GLOBE FOLLOWING PERFORATING INJURY
}

\author{
BY \\ W. E. Heath \\ SENIOR HOUSE SURGEON, ROYAL LONDON OPHTHALMIC HOSPITAL
}

THE following case would appear to be sufficiently rare to justify its publication.

V. E., a labourer, aged 46 years, attended the Royal London Ophthalmic Hospital on May 4, 1929, at 1.30 p.m. He stated that on the previous afternoon he was chipping some concrete with a hammer and chisel when something flew up and struck his left eye. It caused him little trouble at the time, and he continued work. He attended because it still felt as if there was something in his left eye.

On examination the right eye was normal. The left eye was slightly injected, and there was a small perforation of the sclera $3 \mathrm{~mm}$. outside the limbus. The cornea was bright and clear. Several small bubbles of gas were present in the anterior chamber, and during examination a fresh one was seen to come forward through the pupil. The eye was not tender. L.V., shadows.

5.30 p.m. The condition of the left eye was much changed. There was considerable pain in and around the eye. There was much chemosis and the cornea was no longer bright but oedematous and hazy. The anterior chamber was abnormally deep, the globe was very tender, and there was no perception of light in the eye. The patient felt ill, and had a "toxic" appearance. Temperature $98.2^{\circ} \mathrm{F}$., pulse 90 .

8.0 p.m. There was now marked oedema of the left upper lid, greatly increased chemosis, and some proptosis. A large bubble of gas could be seen, distending the anterior chamber and practically filling it. 
8.30 p.m. Evisceration was carried out under general anaesthesia. A corneal incision was made, the bulbar conjunctiva being left intact. There was a definite crackling sensation on cutting into the anterior chamber and several small bubbles of gas appeared when the vitreous was being scooped out, but there was no pus. 25 c.c. of anti-gas serum (B. Welchii) were given intramuscularly and 10 c.c. were injected into the orbit through the lower lid.

The patient's temperature rose to $100^{\circ} \mathrm{F}$. the day following the operation, but apart from that the temperature remained normal. $\mathrm{He}$ was discharged on May 15, having made an uneventful recovery. A stab culture was made from the contents of the vitreous at operation. From this a gas forming organism was grown identical with $\mathrm{B}$.Welchii, of which it appeared to be a pure culture.

There are few cases described of panophthalmitis due to gasforming organisms. James ${ }^{1}$ describes two cases both similar to this in that they both had very acute intraocular infection, without pus formation, following quickly on the perforating wound. In both cases were bubbles of gas seen in the anterior chamber. One case was treated by excision and the other by evisceration. Both made a normal recovery.

Other cases are described by Oreste ${ }^{2}$ and Chaillous ${ }^{3}$. In their series there is a note in each case that the patient was more ill than would be expected in an ordinary panophthalmitis, but there is no mention of gas formation. The B.perfringens was found in each case by routine bacteriological examination. In two cases hypopyon developed.

Lutz ${ }^{4}$ also describes three cases in which a gas-forming organism was found on routine bacteriological examination, but all of them appear to have suffered from what was clinically a panophthalmitis of the usual type.

Ridley $^{\mathbf{b}}$ recorded a case very similar to this one at the last Annual Congress of the Ophthalmological Society of the United Kingdom, the details of which are not yet in print.

I wish to thank Mr. F. A. Juler for permission to publish this case. The bacteriological examination was carried out by Dr. S. H. Browning.

\section{REFERENCES}

1. James, R. R.-Ophthal. Rev, Vol. XXIX, p. 181.

Trans. Ophthal. Soc. U.K., Vol. XXX, p. 179.

2. Oreste.-Ann. d'Ocul., p. 35, 1910.

3. Chaillous.-Ann. d'Ocul., p. 115, 1905.

4. Lutz.-Klin. Monatsbl.f. Augenheilk., Vol. XLVIII, p. 31.

5. Ridley.-Trans. Ophthal. Soc. U.K., Vol. XLIX. 